\title{
PENGEMBANGAN MEDIA PEMBELAJARAN INTERAKTIF MATA PELAJARAN BAHASA INDONESIA UNTUK GURU PENGAJAR SISWA PENYANDANG TUNARUNGU DI SLB NEGERI 1 BULELENG
}

\author{
Ida Ayu Agung Yogi Pradnyani'), Nyoman Sugihartini²), I Made Ardwi Pradnyana3) \\ 1,2,3 Fakultas Teknik Dan Kejuruan, Universitas Pendidikaan Ganesha \\ Email: dayuyogi61@gmail.com, sugihartni@undiksha.ac.id, ardwi.pradnyana@undiksha.ac.id
}

\begin{abstract}
ABSTRAK
Permasalahan yang dialami dalam proses pembelajaran di kelas ketidaktersediaan sarana pembelajaran seperti buku ditambah dengan keterbatasan siswa tunarungu dalam memahami pembelajaran yang bersifat abstrak. Oleh karena itu, perlu adanya pengembangan media pembelajaran yang dapat menunjang pembelajaran yaitu dengan media pembelajaran interaktif pada mata pelajaran bahasa indonesia. Proses pengembangan media pembelajaran mengadaptasi penggunaan model Multimedia Development Life Cycle, yang terdiri dari 6 tahapan yaitu concept, design, material collecting, assembly, testing dan distribution. Implementasi dari media pembelajaran interaktif mata pelajaran bahasa indonesia ini dengan melakukan dua pengujian yaitu alpha testing dan beta testing. Alpha testing dilakukan untuk mengetahui kevalidan media pembelajaran serta kesesuaian isi media pembelajaran sehingga dapat diterapkan, pengujian ini dilakukan oleh ahli isi mata pelajaran dan ahli media. Untuk beta testing dilakukan oleh siswa kelas 1B,3B, dan 5B SLB Negeri 1 Buleleng untuk melakukan uji coba perorangan, kelompok kecil dan uji lapangan. Rata - rata respon siswa terhadap pengembangan media pembelajaran interaktif ini sebesar $92 \%$ dan untuk rata - rata respon guru sebesar $91,11 \%$. Hal ini membuktikan bahwa media pembelajaran dapat digunakan sebagai panduan belajar siswa sehingga dapat meningkatkan fokus belajar pada siswa dan dapat membantu proses pembelajaran di kelas. Jika dikonversikan ke dalam tabel respon siswa dan guru termasuk dalam kategori Sangat Baik.
\end{abstract}

Kata kunci : Media Pembelajaran Interaktif, Tunarungu, Mata Pelajaran Bahasa Indonesia.

\begin{abstract}
Problems experienced in the learning process in the classroom are the unavailability of learning tools such as books coupled with the limitations of deaf students in understanding abstract learning. Therefore, it is necessary to develop learning media that can support learning by interactive learning media on Indonesian subjects. In the process of developing learning media adapting the use of the Multimedia Development Life Cycle model, which consists of 6 stages, namely concept, design, material collecting, assembly, testing and distribution. The implementation of interactive learning media for Indonesian subjects is done by testing two, namely alpha testing and beta testing. Alpha testing is done to determine the validity of learning media and the suitability of the contents of learning media so that it can be applied, this test is carried out by subject matter experts and media experts. For beta testing conducted by students in grades 1B, 3B, and 5B SLB Negeri 1 Buleleng to conduct individual, small group and field trials. The average student response to the development of interactive learning media was $92 \%$ and for the average teacher response was $91.11 \%$. This proves that learning media can be used as student learning guides so that it can increase the focus of learning on students and can help the learning process in the classroom. If converted into a student and teacher response table included in the category of Very Good.
\end{abstract}

Keywords: Interactive Learning Media, Deaf, Indonesian Language Subjects. 


\section{PENDAHULUAN}

Pendidikan merupakan hal yang sangat krusial untuk semua orang, hal ini karena pendidikan adalah salah tolak ukur kemajuan suatu negara. Pendidikan juga merupakan modal yang harus dimiliki selain kemapuan dan pengetahuan untuk dapat hidup di zaman sekarang. Di zaman ini perkembangan teknologi berkembang sangat pesat di berbagai aspek, salah satunya pendidikan. Perkembangan teknologi dalam pendidikan dapat berupa peralihan metode pembelajaran yang tidak hanya menggunakan metode konvensional seperti buku pelajaran dan penjelasan guru, namun pembelajaran efektif yang memanfaatkan teknologi komputer[1]. Salah satu contohnya media pembelajaran yang berbasis multimedia interaktif yang dapat dikembangkan untuk beragam mata pelajaran di sekolah.

Bahasa indonesia merupakan salah satu dari mata pelajaran wajib yang diproleh di sekolah dasar hingga sekolah menengah atas maupun sekolah luar biasa sesuai dengan kurikulum yang diterapkan. Salah satu materi yang dipelajari siswa dalam kurikulum tersebut adalah menguraikan kosakata tentang berbagai jenis benda di lingkungan sekitar. Namun dalam proses pembelajaran bahasa indonesia dengan materi tersebut di SLB Negeri 1 Buleleng terdapat beberapa kendala yang dihadapi oleh guru pengajar antara lain siswa memiliki masalah dalam keterampilan berbahasa dan kesulitan melafalkan kata.

Kendala saat proses pembelajaran di kelas dikarenakan siswa memiliki kekurangan dalam pendengaran atau yang sering disebut dengan tunarungu. Seseorang dikatakan merupakan penyandang tunarungu apabila orang tersebut mempunyai kecacatan pada indra pendengaran. Seseorang berkomunikasi salah satunya dengan menggunakan bahasa, anak tunarungu dengan keterbatasan yang dimiliki mengalami kesulitan untuk memperoleh bahasa dalam komunikasi dengan orang di sekitar. Komunikasi memiliki hubungan yang sangat erat dengan kemampuan bahasa karena seseorang dapat berkomunikasi dengan baik menggunakan bahasa yang benar. Terdapat empat keterampilan dalam berbahasa, yang pertama ketrampilan menyimak, yang kedua keterampilan berbicara, ketiga keterampilan membaca dan yang terakhir keterampilan menulis [2]. Dengan memiliki keterampilan dalam berbahasa akan menunjang keberhasilan dalm mempelajari semua bidang ilmu. Salah satu keterampilan bahasa yang sangat penting dan harus dimiliki oleh semua peserta didik yaitu membaca. Memiliki keterampilan membaca yang baik, maka peserta didik akan dapat meningkatkan hasil belajar.

Berdasarkan hasil wawancara dengan guru bidang studi Bahasa Indonesia kelas 1B bahwa siswa tunarungu di SDLB memiliki masalah dalam keterampilan berbahasa, hal tersebut karena keterbatasan yang dimiliki mengakibatkan siswa susah mengingat kosa kata yang telah di pelajari, kesulitan dalam mengucapkan/melafalkan kata, kurangnya pemahaman dalam kalimat sederhana, kesulitan menuliskan kata yang ingin disampaikan. Hal ini dikarenakan Peserta didik di Sekolah Luar Biasa pada umumnya tidak pernah memperoleh kesempatan Pendidikan Anak Usia Dini (PAUD), keterampilan berbahasanya sama sekali tidak kelihatan. Mengenal huruf, mengucapkan, menyimak apalagi membaca dan menulis tentu belum dapat mereka lakukan. Di samping itu juga untuk fasilitas penunjang pembelajaran yaitu buku juga tidak ada untuk semester 2. Guru dalam proses pembelajaran di kelas mensiasati ketidakadaan buku dalam proses pembelajaran dengan menggunakan media yang dapat membantu siswa memvisualisasi materi yang diberikan. Proses pembelajaran di kelas guru menggunakan media pembelajaran untuk menunjang pembelajaran, media pembelajaran berperan penting dalam proses pembelajaran karena penyajian media pembelajaran beragam seperti grafik, film, slide, foto, serta pembelajaran dengan menggunakan komputer. Penggunaan komputer dalam media pembelajaran sangat penting karena peran komputer dapat menyalurkan, menyimpan dan memproses informasi, dimana proses belajar-mengajar menjadi komunikatif, efektif dan efisien. Salah satu media pembelajaran yang berbasis komputer adalah media interaktif, media pembelajaran interaktif dapat disebut sebagai suatu aplikasi pembelajaran yang ditujukan untuk menyalurkan pesan pembelajaran berupa pengetahuan, keterampilan dan sikap agar dapat merangsang pikiran, perasaan, perhatian dan kemauan anak dalam belajar sehingga secara sengaja proses belajar terjadi, bertujuan dan terkendali [3]

Hasil dari observasi yang dilakukan, saat proses penyampaian materi kepada siswa tunarungu dengan media pembelajaran sederhana masih dirasa belum efektif dan siswa cepat merasa bosan sehingga diperlukan sebuah media pembelajaran yang dapat menarik perhatian siswa untuk konsentrasi menerima materi yang diajarkan dan dapat memfasilitasi interaksi dengan media. Interaksi dilakukan oleh guru yang mengajar siswa tunarungu, hal ini dikarenakan siswa tunarungu masih belum bisa mengoperasikan komputer dan fasilitas seperti komputer tidak tersedia sehingga pengguna media ini adalah guru dan tugas siswa dalam media ini adalah menyimak materi dari 
media. Media pembelajaran interaktif dirasa lebih baik dibandingkan dengan menggunakan media sederhana dan ceramah. Hal ini karena karakteristik siswa tunarungu adalah anak visual dimana mereka akan tertarik apabila pembelajaran menggunakan media yang didalamnya terdapat beragam variasi animasi, beragam warna dan tampilan yang menarik sehingga dapat meningkatkan konsentrasi belajar pada siswa. Anak tunarungu dalam proses pembelajaran mengalihkan pengamatannya kepada mata karena kurang berfungsinya pendengan sehingga anak tunarungu disebut sebagai anak visual[4]. Proses pembelajaran untuk siswa tunarungu harus menyesuaikan dengan karakteristiknya. [5]

Media pembelajaran interaktif yang dikembangkan ditujukan untuk semua level klasifikasi tunarungu. Hal ini berdasarkan hasil wawancara dengan wali kelas 1B bahwa dalam penerimaan siswa baru, tidak mewajibkan melampirkan hasil tes untuk mengetahui sisa pendengaran siswa dan juga guru tidak bisa mengelompokkan siswa berdasarkan klasifikasi tunarungu dikarenakan ketidaktersediaan ruang kedap suara yang digunakan untuk melakukan tes audiometri. Hal yang dilakukan oleh guru untuk dapat mengetahui sisa pendengaran siswa melalui BKPBI (Bina Komunikasi Persepsi Bunyi dan Irama). Siswa mendapatkan BKPBI mulai dari SD - SMP. BKPBI yang dilakukan oleh guru terdiri dari bina komunikasi dan bina persepsi bunyi dan irama [6]. Berdasarkan observasi yang dilakukan, guru sudah menerapkan BKPBI dalam setiap mata pelajaran, seperti melakukan bina komunikasi melalui oral, aural dan tulisan untuk melatih sisa pendengaran bagi anak tunarungu. Media yang dapat digunakan untuk latihan BKPBI dapat berupa media stimulasi visual, media stimulasi auditoris dan media stimulasi vibrasi[7]. Pembelajaran BKPBI ini, membantu guru dapat mengetahui apakah siswa memiliki sisa pendengaran atau tidak.

Berdasarkan permasalahan yang ada peneliti menemukan sebuah solusi untuk mengatasi hal tersebut dengan pengembangan sebuah media pembelajaran interaktif untuk mata pelajaran bahasa indonesia bagi guru pengajar tunarungu, sehingga peneliti terinspirasi untuk membuat penelitian berjudul "Pengembangan Media Pembelajaran Interaktif Mata Pelajaran Bahasa Indonesia Untuk Guru Pengajar Siswa Penyandang Tunarungu Di SLB Negeri 1 Buleleng".

\section{METODE}

Pada penelitian ini menggunakan model pengembangan mengadaptasi dari model pengembangan Multimedia Development Lyfe Cycle (MDLC). Model pengembangan ini merupakan model pengembangan yang terdiri atas 6 tahapan yang tidak harus berurutan dalam penggunaanya, dengan kata lain tahapan dari model pengembangan ini dapat saling bertukar posisi [8]. Tahapan MDLC terdiri atas concept (pengonsepan), design (perancangan), material collecting (pengumpulan material), assembly (pembuatan), testing (pengujian), dan distribution (pendistribusian). Dapat dilihat pada gambar 1.

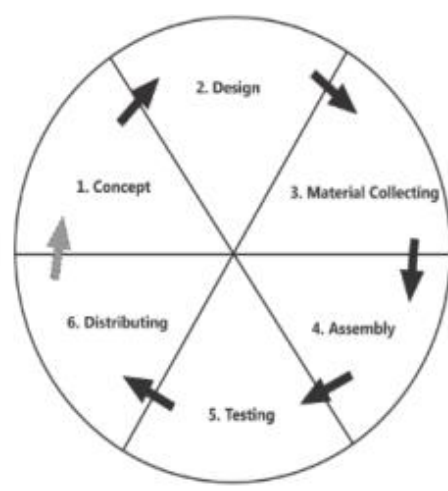

Gambar 1. Model MDLC

Sumber : (Binanto, 2010)

\section{a) Concept}

Tahap pertama dalam model MDLC adalah concept yang merupakan tahap untuk pengembang menentukan tujuan dan pengguna program yang akan dikembangkan (identifikasi audience). Pada tahap ini juga digunakan untuk menentukan aplikasi jenis apa yang akan dikembangkan seperti presentasi / interaktif dan/ yang lainnya, serta menentukan tujuan aplikasi yang dikembangkan seperti hiburan / pelatihan / pembelajaran dan/ lainnya. Sebelum melakukan tahapan pengkonsepan, perlu dilakukannya analisis. Hasil analisis sumber belajar diketahui bahwa sumber belajar untuk proses pembelajaran di kelas berasal dari internet dan guru mencari materi baik berupa gambar atau video yang relevan dengan materi yang diajarkan. Selain itu, ketidaktersediaan buku pegangan baik untuk guru maupun siswa mata pelajaran tema 7 menyebabkan peserta didik memperoleh materi yang 
hanya diberikan oleh guru. Untuk hasil analisis karakteristik peserta didik berdasarkan pengamatan proses pembelajaran di kelas diketahui bahwa gaya belaja peserta didik bersifat visual karena peserta didik dalam proses pembelajaran lebih senang diberikan materi berupa gambar atau video yang menarik.

Setelah melakukan analisis berdasarkan sumber belajar dan karakteristik peserta didik maka dilanjutkan ke tahap pengkonsepan. Secara umum tahap ini digunakan untuk menentukan konsep materi pembelajaran, dan menentukan konsep isi media pembelajaran.

1. Konsep Materi Pembelajaran

Materi pembelajaran dalam media ini mengacu pada silabus SLB Negeri 1 Buleleng Tahun Pelajaran 2019/2020, setelah melakukan analisa terhadap isi silabus maka dapat diketahui materi apa saja yang perlu diperkuat dengan bantuan media. Di tahap ini peneliti mengkaji indikator dan kompetensi dasar yang akan digunakan sebagai acuan dalam pembuatan media.

2. Konsep Isi Media Pembelajaran

Tahap pengkonsepan isi media pembelajaran dilakukan untuk menganalisa perangkat lunak apa saja yang dapat digunakan terkait dalam pembuatan media yang akan dikembangkan, dengan tujuan untuk memaksimalkan teknologi yang digunakan dalam bidang multimedia interaktif agar dapat mudah diterima oleh peserta didik. Media pembelajaran yang dihasilkan berupa sebuah animasi 2D dengan menggunakan adobe flash CS6 dimana dalam animasi akan menjelaskan materi kosa kata berbagai jenis benda di lingkungan sekitar pada mata pelajaran Bahasa Indonesia. Produk yang dihasilkan akan dikonversikan dalam format file berupa *exe, karena lebih mudah dioperasikan.

\section{b) Design}

Tahap design (perancangan) merupakan tahapan untuk membuat spesifikasi mengenai arsitektur program, tampilan dan kebutuhan material untuk program yang dikembangkan. Tahap design ini digunakan untuk merancang materi dalam media pembelajaran interaktif dan membuat storyboard. Tujuan dari pembuatan storyboard dan merancang materi agar memudahkan pada proses pembuatan media sehingga pembuatan media menjadi terstruktur dan terarah. Rancangan yang dibuat dalam tahap design meliputi :

1. Membuat storyboard untuk menggambarkan setiap scene dilengkapi dengan mencantumkan semua objek media dan tautan ke scene lain.

2. Membuat flowchart untuk mengambarkan setiap langkah pembuatan media secara logika dan menggambarkan alur setiap scenenya.

3. Membuat user interface untuk menggambarkan rancangan tampilan media.

\section{c) Material Collecting}

Material Collecting merupakan tahap untuk mengumpulkan bahan yang sesuai dengan kebutuhan pengembangan produk. Bahan-bahan dapat berupa gambar clip art, foto, animasi, video, audio yang dapat diperoleh secara gratis atau dengan pemesanan kepada pihak lain. Tahap ini juga bisa dikerjakan paralel dengan tahap assembly. Pada tahap pengumpulan materi ini peneliti mengunduh buku TEMATIK Terpadu Kurikulum 2013 kelas 1 tema 7 untuk mengetahui gambaran awal materi - materi yang akan diajarkan dan juga berdiskusi dengan guru bersangkutan. Selanjutnya mengunduh gambar yang sesuai dengan materi yang dikembangkan dan untuk lebih detail peneliti melakukan proses pengumpulan bahan sebagai berikut :

1. Mengumpulkan bahan - bahan materi dan membuat soal - soal yang akan ditampilkan dalam media pembelajaran

2. Mengumpulkan gambar penunjang yang digunakan sebagai objek animasi pada media pembelajaran

3. Mengumpulkan audio sebagai musik latar pada media pembelajaran

\section{d) Assembly}

Tahap pembuatan merupakan tahap dimana seluruh objek media seperti teks, gambar, audio, dan material lainnya yang telah dikumpulkan sebelumnya dibuat menjadi sebuah media pembelajaran yang tersusun dalam satu kesatuan yang utuh sesuai dengan story board yang telah dirancang. Pengembangan media pembelajaran ini membahas pada materi benda, hewan dan tumbuhan di sekitar. Secara gari besar, media pembelajaran ini terdiri atas menu petunjuk, indikator dan tujuan pembelajaran, materi dan evaluasi. Media pembelajaran ini menggabungkan penggunaan teks, gambar, animasi, video dan juga musik dengan menggunakan tombol - tombol navigasi yang menjadikan aplikasi media pembelajaran ini lebih interaktif dan menarik.

Pembuatan media pembelajaran ini menggunakan software Adobe Flash CS6 dan untuk gambar - gambar pendukung dibuat di Adobe Illustrator CS6 atau di Adobe Photoshop CS6. Pertama 
yang dilakukan adalah membuat desain pada Adobe Flash CS6 sesuai dengan storyboard, setelah itu diberikan action script agar media dapat berjalan sesuai dengan yang diinginkan.

\section{e) Testing}

Testing sering disebut sebagai tahap pengujian alpha dimana pengujian dilakukan oleh pembuat dan biasanya tahap testing dilakukan setelah selesai tahap pembuatan (assembly) untuk menguji apakah aplikasi/program bekerja dan apakah ada kesalahan atau tidak. Pengujian dilakukan untuk mengetahui apakah aplikasi dapat berjalan sesuai yang dirancang dan mengetahui apakah terdapat error dalam media pembelajaran yang dibuat. Terdapat dua jenis pengujian yang digunakan, yaitu pengujian alpha dan pengujian beta. Pengujian alpha dalam pengembangan media pembelajaran seperti menguji fungsi tombol apakah sudah berjalan, menampilkan setiap halaman. Apabila ada error maka produk akan segera diperbaiki. Jika pengujian alpha sudah dinyatakan lolos maka dilanjutkan dengan pengujian beta, dimana pengujian ini dilakukan oleh pengguna, dengan membuat angket mengenai produk yang dibuat.

\section{f) Distribution}

Tahap ini merupakan tahap akhir dalam pengembangan media pembelajaran dimana setelah selesai diujikan dan dinyatakan layak maka produk di-export menjadi file *.exe, dengan tujuan produk tersebut dapat dijalankan dengan mudah di perangkat komputer dan disimpan di dalam media penyimpanan seperti hardisk dan CD. Setelah disimpan dalam media penyimpanan, produk telah siap didistribusikan ke sekolah.

\section{HASIL DAN PEMBAHASAN}

A. Hasil Implementasi

Penelitian pengembangan ini menghasilkan produk berupa media pembelajaran interaktif mata pelajaran bahasa indonesia untuk guru pengajar siswa penyandang tunarungu di Slb Negeri 1 Buleleng.Pembuatan media pembelajaran ini menggunakan software Adobe Flash CS6 dan untuk gambar - gambar pendukung dibuat di Adobe Illustrator CS6 atau di Adobe Photoshop CS6. Pertama yang dilakukan adalah membuat desain pada Adobe Flash CS6 sesuai dengan storyboard, setelah itu diberikan action script agar media dapat berjalan sesuai dengan yang diinginkan. Secara garis besar media pembelajaran ini terdiri atas Petunjuk, Indikator dan Tujuan Pembelajaran, Materi, dan Kuis. Berikut adalah hasil pembuatan media pembelajaran interaktif :

\section{Tampilan Halaman Judul Media Pembelajaran}

Halaman judul merupakan halaman pertama yang akan muncul ketika media pembelajaran dijalankan. Tampilan halaman ini diawali dengan animasi gambar dan juga animasi teks. Pada halaman judul terdapat judul media pembelajaran dan tombol masuk. Tombol masuk digunakan untuk menuju pada halaman menu dari media pembelajaran ini.

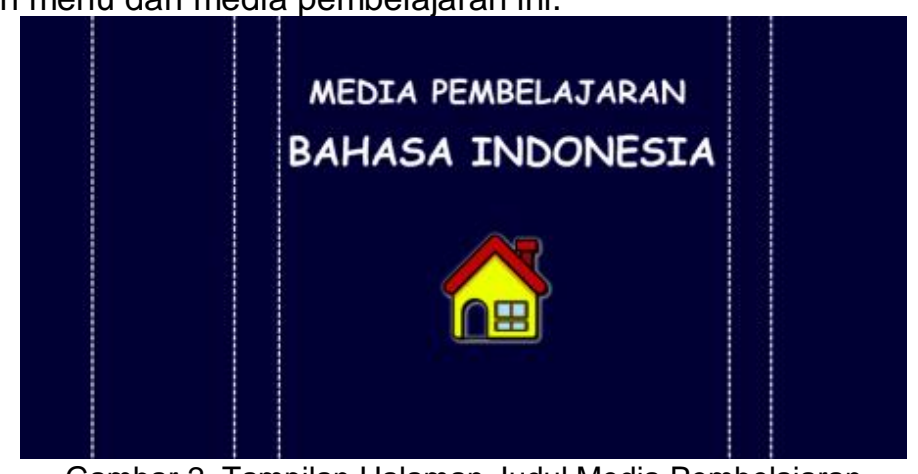

Gambar 2. Tampilan Halaman Judul Media Pembelajaran

2. Tampilan Menu pada Media Pembelajaran

Setelah menekan tombol masuk, maka menuju halaman menu pada media pembelajaran ini. Pada halaman menu terdiri atas 4 menu yaitu petunjuk, indikator dan tujuan pembelajaran, materi dan quis. Pada pojok kanan atas terdapat dua tombol yaitu tombol keluar dan tombol volume. Tombol keluar berfungsi untuk mengakhiri media sedangkan tombol volume digunakan untuk menghidupkan atau mematika backsound. 


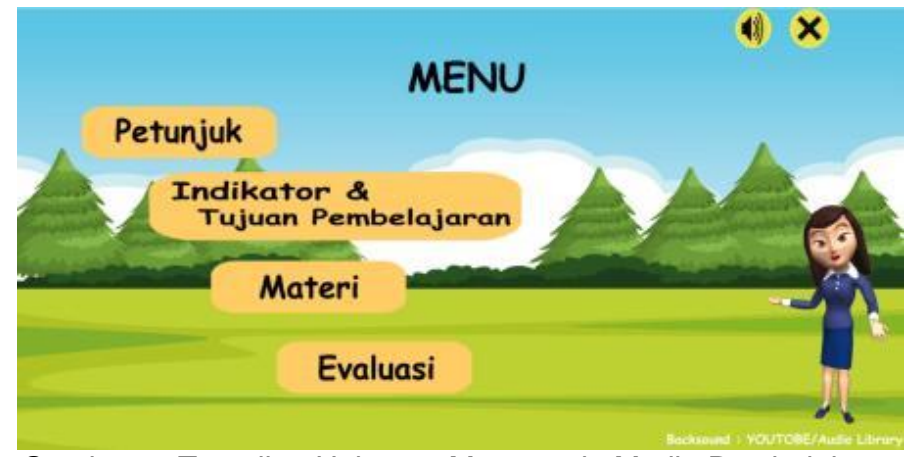

Gambar 3. Tampilan Halaman Menu pada Media Pembelajaran

\section{Tampilan Halaman Petunjuk}

Menu petunjuk digunakan untuk membantu pengguna untuk mengetahui fungsi masing-masing tombol pada media pembelajaran sehingga dapat mempermudah dalam mengoperasikan media pembelajaran.

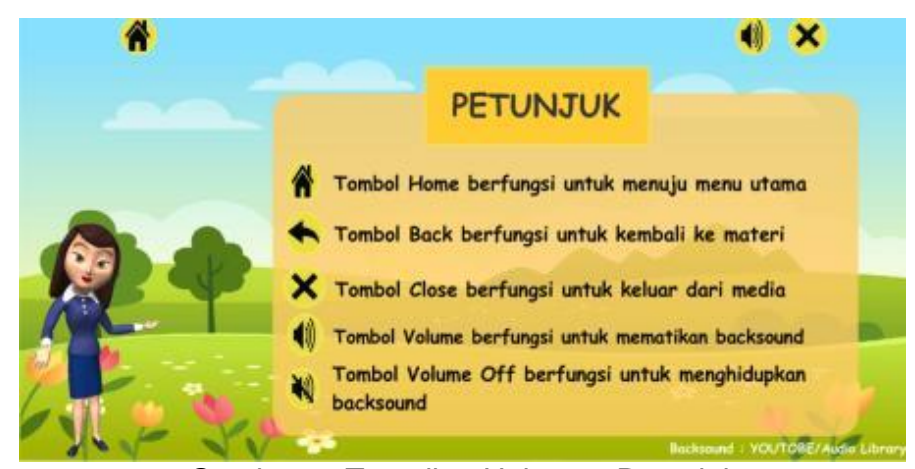

Gambar 4. Tampilan Halaman Petunjuk

4. Tampilan Halaman Indikator dan Tujuan Pembelajaran

Menu selanjutnya yang ada di media pembelajaran adalah indikator dan tujuan pembelajaran. Halaman indikator dan tujuan pembelajaran memiliki dua submenu yang terdiri atas indikator dan tujuan pembelajaran.

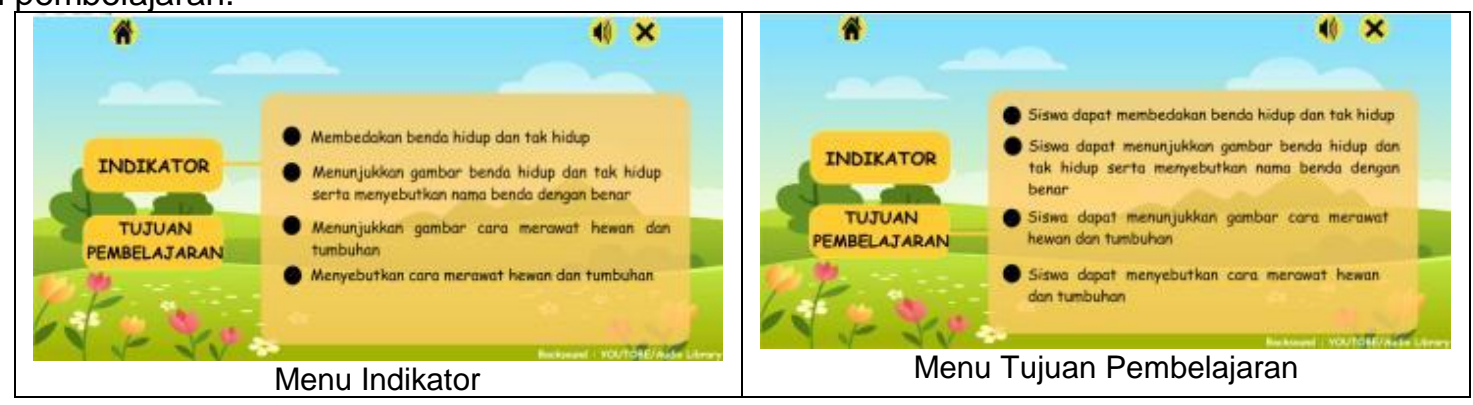

Gambar 5. Tampilan Menu Indikator dan Tujuan Pembelajaran

\section{Tampilan Halaman Materi}

Pada menu materi terdapat 4 pokok materi yaitu video, benda, hewan dan tumbuhan. Fungsi dari 4 menu tersebut, diantarnya (1) submenu video untuk menuju ke halaman materi yang menjelaskan secara umum ciri - ciri benda hidup dan tak hidup beserta contohnya, (2) submenu benda berfungsi untuk menuju halaman materi yang menjelaskan nama benda beserta gambarnya, (3) submenu hewan digunakan untuk menuju halaman materi yang menjelaskan nama hewan beserta gambarnya dan juga cara merawat hewan, (4) submenu tumbuhan digunakan untuk menuju halaman materi yang menjelaskan nama tumbuhan, bagian tumbuhan beserta gambarnya dan juga cara merawat tumbuhan. 


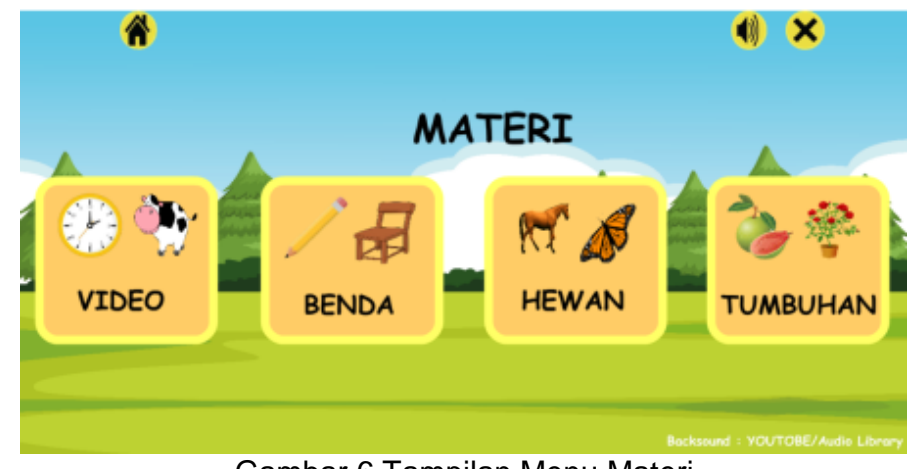

Gambar 6.Tampilan Menu Materi

\section{Tampilan Halaman Quis}

Pada tampilan awal halaman quis terdapat empat submenu yang terdiri atas tebak benda, tebak hewan, tebak tumbuhan dan evaluasi. Untuk soal tebak, baik tebak benda, tebak hewan maupun tebak tumbuhan terdiri dari 5 soal dan untuk evaluasi terdiri dari 10 soal yang mencakup materi keseluruhan. Jika pengguna menjawab soal maka akan ada notifikasi keterangan jawaban benar atau salah. Pada soal terakhir akan ada tombol selesai yang berfungsi untuk mengulangi kembali mengerjakan soal quis.

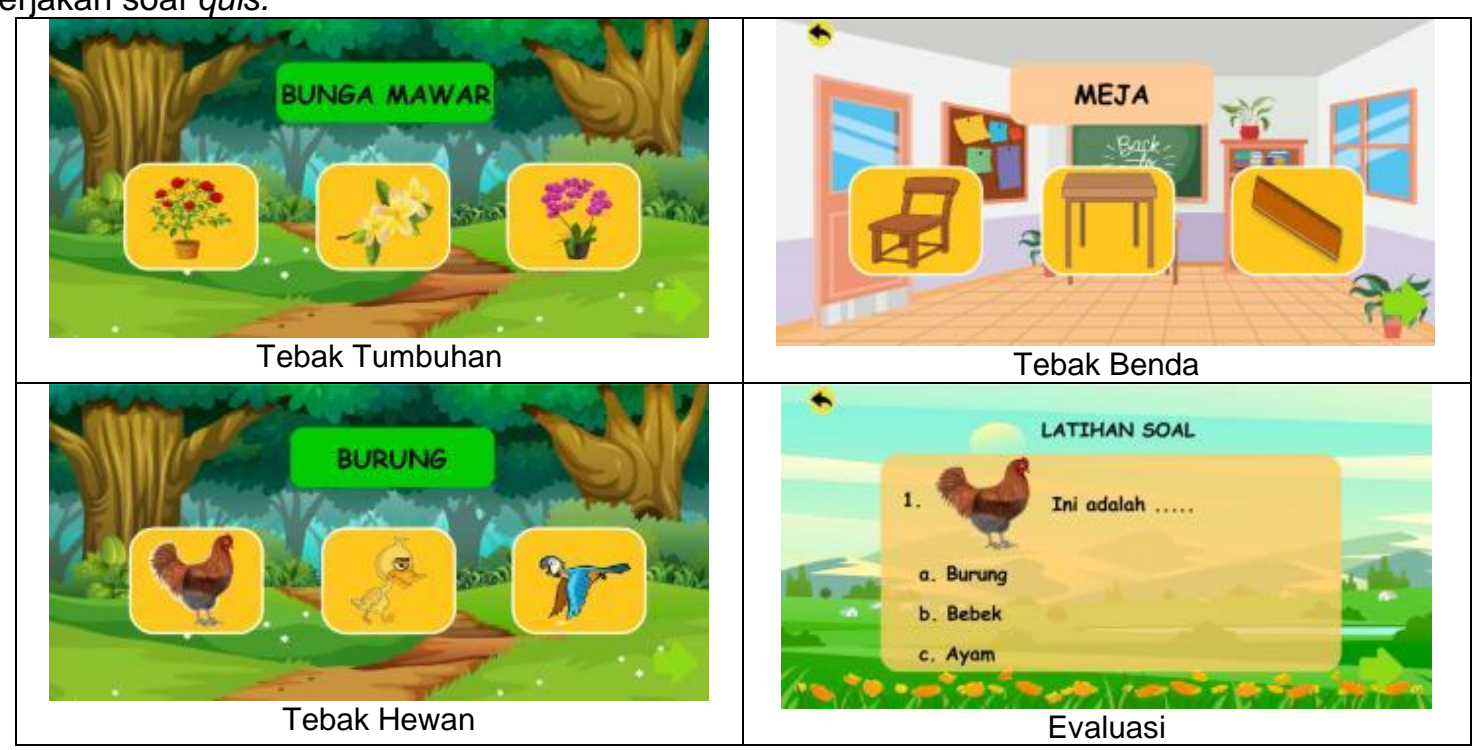

Gambar 7. Tampilan Menu Kuis

\section{B. Hasil Pengujian}

Berikut ini merupakan hasil pengujian "Pengembangan Media Pembelajaran Interaktif Mata Pelajaran Bahasa Indonesia Untuk Guru Pengajar Siswa Penyandang Tunarungu Di SLB Negeri 1 Buleleng" yang terdiri atas uji ahli isi, uji ahli media, uji respon siswa dan uji respon guru.

1. Hasil Pengujian Ahli Isi Mata Pelajaran

Untuk melakukan uji validasi ahli isi, melibatkan 2 orang ahli dimana kedua ahli merupakan guru mata pelajaran bahasa indonesia karena keduanya mengetahui secara detail materi dan proses pembelajaran yang dilakukan. Hasil dari uji validitas ini sebagai berikut :

$$
\text { Validitas isi }=\frac{D}{A+B+C+D}=\frac{12}{0+0+0+12}=1.00
$$

Berdasarkan hasil perhitungan validitas isi diperoleh nilai 1.00, maka dapat disimpulkan bahwa berdasarkan tingkat pencapaian isi dari kriteria Gregory berada pada tingkat "Sangat Tinggi". $\mathrm{Hal}$ ini mengindikasikan bahwa media pembelajaran interaktif dinyatakan layak untuk dilanjutkan dan sudah layak untuk digunakan dalam proses pembelajaran bahasa indonesia. Produk pengembangan media pembelajaran interaktif ini memperoleh pencapaian pada kategori "Sangat Tinggi", namun terdapat saran yang diberikan oleh ahli isi menjadi pertimbangan untuk kesempurnaan media pembelajaran ini. Adapun masukan / saran yang diberikan oleh ahli yaitu durasi video dalam media pembelajaran terlalu cepat. 


\section{Hasil Penilaian Ahli Media Pembelajaran}

Ahli yang digunakan untuk validasi ahli media ini berjumlah dua ahli dimana berasal dari dosen Pendidikan Teknik Informatika yang ahli dalam bidang media pembelajaran. Berdasarkan hasil pengujian ahli media terdapat beberapa saran yang diberikan oleh para ahli sebagai berikut, backsound tidak default ON ketika aplikasi dijalankan, penempatan tombol home dan exit pada tampilan video berada di luar tampilan video, serta warna teks dalam video kurang jelas dilihat. Hasil pengujian diperoleh sebagai berikut :

$$
\text { Validitas isi }=\frac{D}{A+B+C+D}=\frac{20}{0+0+0+20}=1.00
$$

Hasil perhitungan validitas isi diperoleh nilai 1.00. Berdasarkan dari hasil tersebut maka dapat disimpulkan bahwa tingkat pencapaian media dari media pembelajaran interaktif adalah "Sangat Tinggi". Hal ini mengindikasikan bahwa media pembelajaran interaktif dinyatakan layak untuk dilanjutkan dan sudah layak untuk digunakan dalam proses pembelajaran bahasa indonesia.

\section{Hasil Penilaian Respon Siswa}

Uji respon siswa terhadap media pembelajaran ini peneliti menggunakan angket yang disebar dalam tiga kategori pengujian[9] terdiri atas:

a. Hasil Penilaian Respon Uji Perorangan

Tahap pengujian perorangan dilakukan setelah melewati tahap pengujian dari para ahli isi dan media dan telah melakukan revisi sesuai dengan saran yang diberikan oleh para ahli. Pada tahap pengujian ini, dengan situasi pandemi seperti ini guru memberikan materi berupa media pembelajaran ini yang direkam dan dikirim kepada siswa. Subjek dari uji coba perorangan adalah 3 orang siswa tunarungu kelas 3B di SLB Negeri 1 Buleleng yang terdiri atas satu orang dengan prestasi belajar tinggi, satu orang dengan pretasi belajar sedang dan satu lagi orang dengan prestasi belajar rendah. Pemilihan siswa berdasarkan prestasi belajar siswa direkomendasikan oleh wali kelas 3B. Pengujian ini dilakukan dengan memberikan media pembelajaran melalui grup WhatsApp kelas, kemudian siswa menonton video yang diberikan oleh guru. Pada pengujian perorangan ini siswa yang dijadikan responden juga menilai media pembelajaran berdasarkan pengalaman siswa menggunakannya menggunakan instrumen angket yang dibantu oleh orang tua siswa atau guru pengajar dikarenakan kendala orang tua yang tidak memiliki prasarana yang mendukung.

Subjek uji coba perorangan media pembelajaran ini adalah 3 orang dari siswa kelas 3B. Hasil angket uji coba yang telah diisi oleh ketiga siswa ini, diketahui bahwa masing - masing siswa memberikan tanggapan yang sangat baik dan ada 1 siswa yang memberikan tanggapan baik Rata rata penilaian ketiga orang siswa ini adalah 90,22 \%. Jika dikonversikan kedalam tabel respon siswa maka dapat dikatakan bahwa respon siswa berada dalam kategori sangat positif .

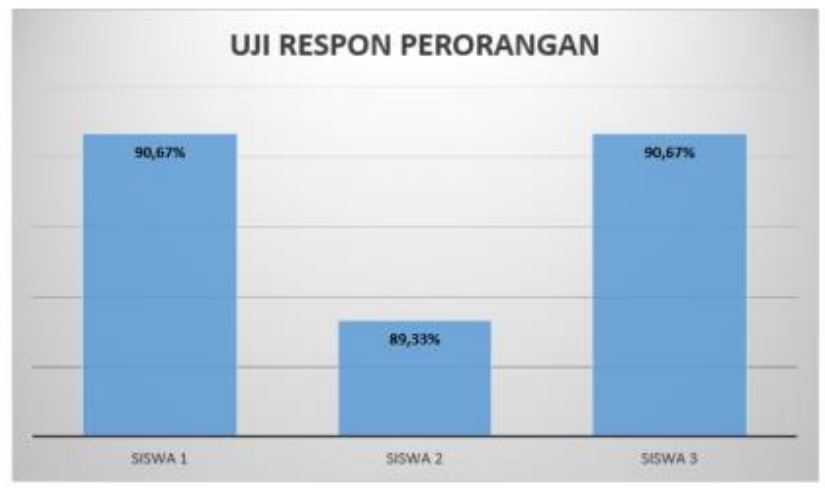

Gambar 7. Hasil Uji Respon Perorangan

b. Hasil Penilaian Respon Uji Kelompok Kecil

Subjek uji coba kelompok kecil media pembelajaran ini adalah 4 orang dari siswa kelas 3B dan 7 orang dari kelas 5B. Hasil angket uji coba yang telah diisi oleh kesebelas siswa ini, diketahui bahwa masing - masing siswa memberikan tanggapan yang sangat baik dan ada 1 orang siswa yang memberikan tanggapan baik. Rata - rata penilaian kesebelas orang siswa ini adalah 91,75 \%. Jika dikonversikan kedalam tabel respon siswa maka dapat dikatakan bahwa respon siswa berada dalam kategori sangat positif. 


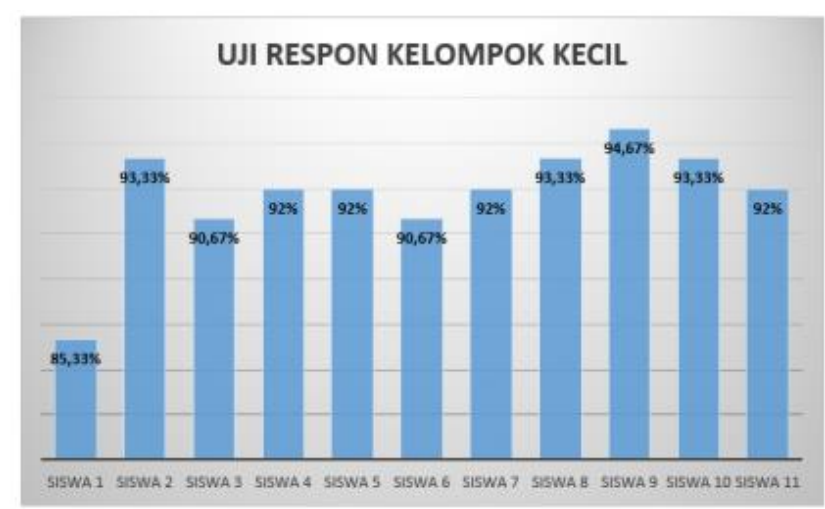

Gambar 8. Hasil Uji Respon Kelompok Kecil

c. Hasil Penilaian Respon Uji Lapangan

Subjek uji coba perorangan media pembelajaran ini adalah 4 orang dari siswa kelas 1B. Hasil angket uji coba yang telah diisi oleh keempat siswa ini, diketahui bahwa masing - masing siswa memberikan tanggapan yang sangat baik dan juga ada 1 orang siswa yang memberikan tanggapan baik maupun sangat kurang. Rata - rata penilaian keempat orang siswa ini adalah $92 \%$. Jika dikonversikan kedalam tabel respon siswa maka dapat dikatakan bahwa respon siswa berada dalam kategori sangat positif dan tidak ada revisi yang dilakukan berdasarkan pada masukan saat pengujian kelompok kecil.

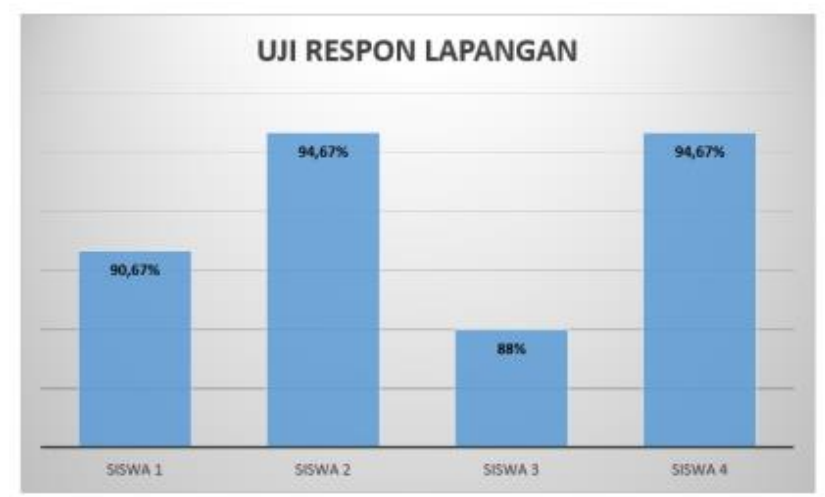

Gambar 9. Hasil Uji Respon Lapangan

\section{Hasil Penilaian Respon Guru}

Subjek dari penilaian respon guru adalah 3 guru pengajar siswa tunarungu kelas 1B, 3B dan kelas 5B di SLB Negeri 1 Buleleng. Pemilihan guru disesuaikan dengan kelas yang digunakan untuk uji coba perorangan, kelompok kecil dan juga uji lapangan. Pada pengujian respon guru ini guru juga menilai media pembelajaran berdasarkan pengalaman guru menggunakannya menggunakan instrumen angket.

Subjek respon guru pada media pembelajaran ini adalah 3 orang guru yang mengajar siswa tunarungu. Hasil angket uji coba yang telah diisi oleh ketiga guru ini, diketahui bahwa masing masing guru memberikan tanggapan yang sangat baik. Rata - rata penilaian ketiga orang guru ini adalah $91,11 \%$. Jika dikonversikan kedalam tabel respon guru maka dapat dikatakan bahwa respon guru berada dalam kategori sangat positif. 


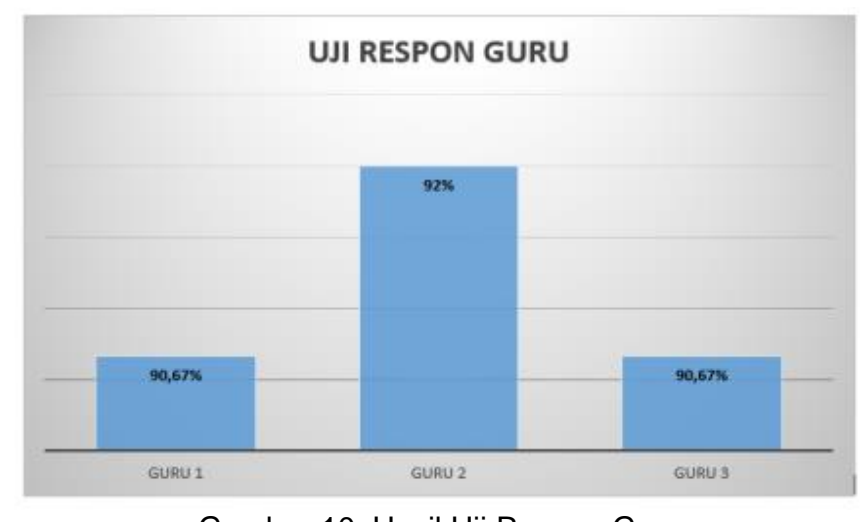

Gambar 10. Hasil Uji Respon Guru

Pada saat pengujian berlangsung siswa terlihat fokus memperhatikan media dan ikut memperagakan animasi yang ada dalam media. Siswa akan lebih mudah untuk mengerti dan memahami materi yang diajarkan bila siswa secara langsung mempraktikannya. Hal ini menunjukkan bahwa media pembelajaran interaktif yang dikembangkan dapat meningkatkan minat siswa. Dalam pengisian angket respon siswa dibantu oleh orang tua siswa [10]. Hasil angket yang diberikan, terdapat beberapa butir pernyataan siswa menjawab kurang setuju seperti "Media pembelajaran interaktif yang digunakan dalam pembelajaran mempersulit saya dalam pemahaman materi-materi bahasa indonesia" yang mana dapat diartikan bahwa siswa lebih tertarik belajar menggunakan media pembelajaran interaktif. Pelaksanaan implementasi media yang dilakukan masih belum maksimal karena terkendala kondisi pandemi dan media yang dikembangkan ini seharusnya media pembelajaran untuk digunakan di kelas serta perlu adanya pendampingan guru. Saat siswa mempelajari media yang diberikan oleh guru tidak semua orang tua mendampingi siswa belajar. Rendah kesadaran orang tua dengan anak berkebutuhan khusus salah satu tantangan dari penyelenggaraan sekolah inklusi, jika orang tua memiliki kesadaran akan anak berkebutuhan khusus maka anak tersebut akan dapat mengembangkan potensi yang dimiliki secara maksimal [11].

\section{SIMPULAN DAN SARAN}

Berdasarkan hasil penelitian dan pembahasan pada penelitian Pengembangan Media Pembelajaran Interaktif Mata Pelajaran Bahasa Indonesia untuk Guru Pengajar Siswa Penyandang Tunarungu di SLB Negeri 1 Buleleng, menggunakan metode pengembangan MDLC yang terdiri atas enam tahapan yaitu Concept, Design, Material Collecting, Assembly, Testing dan Distribution. Pada tahap pengujian dilakukan dua pengujian yaitu Alpha Testing dan Beta Testing. Alpha Testing bertujuan untuk mengetahui apakah media pembelajaran ada kesalahan atau tidak serta apakah media pembelajaran sudah sesuai dengan kebutuhan pengguna sehingga media pembelajaran dapat diterapkan. Untuk pengujian Beta Testing dilakukan oleh sasaran pengguna yang terdiri atas pengujian perorangan menggunakan siswa kelas $3 \mathrm{~B}$, uji coba kelompok kecil menggunakan siswa kelas $3 \mathrm{~B}$ dan $5 \mathrm{~B}$, uji coba lapangan menggunakan siswa kelas 1B dan uji respon guru berjumlah 3 orang di SLB Negeri 1 Buleleng. Rata - rata respon siswa terhadap Pengembangan Media Pembelajaran Interaktif Mata Pelajaran Bahasa Indonesia untuk Guru Pengajar Siswa Penyandang Tunarungu yaitu 92\%. Pengembangan Media Pembelajaran Interaktif Mata Pelajaran Bahasa Indonesia untuk Guru Pengajar Siswa Penyandang Tunarungu untuk siswa kelas 1B di SLB Negeri 1 Buleleng dapat dijadikan sumber belajar bagi siswa. Media pembelajaran digunakan sebagai panduan belajar sehingga dapat meningkatkan minat belajar siswa dan membantu proses pembelajaran siswa di sekolah. Hal ini dibuktikan dengan hasil respon siswa sebesar $92 \%$ yang bila dikonversikan ke dalam tabel respon siswa termasuk dalam kategori Sangat Positif. Untuk rata - rata respon guru sebesar $91,11 \%$ jika dikonversikan kedalam tabel respon guru maka dapat dikatakan bahwa respon guru berada dalam kategori Sangat Positif.

Berdasarkan hasil penelitian pengembangan dan kesimpulan, maka saran yang dapat diberikan Pengembangan Media Pembelajaran Interaktif Mata Pelajaran Bahasa Indonesia untuk Guru Pengajar Siswa Penyandang Tunarungu ini perlu banyak perbaikan menyesuaikan dengan perkembangan teknologi yang dikembangkan untuk mengembangkan media pembelajaran sangat cepat. Media pembelajaran interaktif dikembangkan sesuai dengan karakteristik siswa tunarungu, bagi pembaca dapat mengembangkan penelitian media pembelajaran untuk siswa tunarungu dengan kelas yang berbeda ataupun mata pelajaran yang berbeda atau dapat mengembangkan media pembelajaran untuk siswa tunanetra. Proses implementasi disarankan untuk memberikan panduan 
teknis mengenai pengisian angket dan mengikutsertakan orang tua sebagai pedamping dalam proses pembelajaran anak.

\section{DAFTAR PUSTAKA}

[1] A. S. T. S, A. Johari, and A. Hamidah, "Pengembangan Media Pembelajaran Interaktif menggunakan Macromedia Flash 8 Pada Materi Sistem Saraf Untuk Kelas XI SMA," pp. 1-9, 2017.

[2] F. E. Nandatiar, "Model Induktif Kata Bergambar Terhadap Kemampuan Menyusun Kalimat Acak S-P-O-K Siswa Tunarungu di SDLB-B Diajukan kepada Universitas Negeri Surabaya Model Induktif Kata Bergambar Terhadap Kemampuan Manyusun Kalimat Acak S-P-O-K Siswa Tunarungu di SDLB-B," pp. 1-13, 2017.

[3] I. W. Darnanta, Pengembangan Media Pembelajaran Mata Pelajaran Matematika Untuk Penyandang Tunagrahita ( Studi Kasus : Siswa Kelas D2 / Semester 2 SLB Negeri 2 Buleleng ). 2019.

[4] J. Marzal, "Desain Media Pembelajaran Bahasa Inggris Untuk Siswa Tunarungu Berbantuan Teknologi Informasi dan Komunikasi," Tekno-Pedagogi, vol. 4, no. 2, pp. 32-44, 2014.

[5] N. K. S. Eka Utari, "Peningkatan Pemahaman Siswa Tunarungu Menggunakan Model Pembelajaran Langsung Bermedia Gambar," Incl. J. Spec. Educ., vol. II, no. 01, pp. 33-61, 2016.

[6] Khalilurrahman and M. Afdhal, "Penerapan Metode Pembelajaran BKPBI (Bina Komunikasi Persepsi Bunyi Dan Irama) Untuk Anak Yang Berkebutuhan Khusus (Tunarungu) Di SLB Bina Siwi Banjul Yogyakarta," Khazanah, vol. 4, no. 1, pp. 89-100, 2011.

[7] D. Gunawan, "Optimalisasi Pendengaran dengan Bina Komunikasi Persepsi Bunyi Irama," Jassi Anakku, vol. 12, no. 2, pp. 181-192, 2013.

[8] I. Binanto, Multimedia Digital - Dasar Teori dan Pengembangannya. Yogyakarta: CV. Andi Offset, 2010.

[9] A. A. Gde Ekayana, "Pengembangan Modul Pembelajaran Mata Kuliah Internet of Things," J. Pendidik. Teknol. dan Kejuru., vol. 16, no. 2, p. 159, 2019.

[10] V. Andriani, "Strategi Pembinaan Anak Autis Tuna Rungu dalam Pengembangan Interaksi Sosial (Studi Kasus di SLB Negeri Kecamatan Sinjai Utara Kabupaten Sinjai)," 2016.

[11] J. C. Pratiwi, "Sekolah Inklusi Untuk Anak Berkebutuhan Khusus : Tanggapan Terhadap Tantangan Kedepannya," Pros. Semin. Nas. Pendidik. "Meretas Sukses Publ. IIm. Bid. Pendidik. J. Bereputasi," no. November, pp. 237-242, 2015. 